\title{
立型蒸溜业鉛工場の建設と操業*
}

(昭和 34 年度渡辺賞牌受賞)

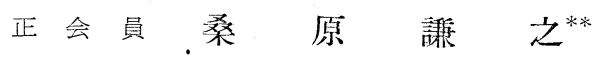

\section{The Construction and Operation of the Vertical Retort Zinc Plant}

\author{
Kenshi KUWAHARA
}

With the purpose of rehabilitation and modernization of zinc smelting, the vertical retort plant was constructed at Miike smelter, and it was put into operation in January 1954. This plant is characterized from the regular process with the following features;

(1) The application of compression spring for the retort binding.

(2) The separate support of the retort upper extension.

(3) The application of AMCO-Recuperator separately installed from the distillation furnace.

The operation result has shown that an average output of 1100 tons of metallic zinc per month from 8 retorts with $97 \%$ elimination and $94 \%$ recovery has been maintained by firing at $1250^{\circ} \mathrm{C}$. The grade of zine from vertical retort is $99.7 \sim 99.9 \%$.

The three zinc smelting processes of horizontal retort, electrolytic zinc and vertical retort are now in operation in parallel at Miike. The smelting cost of the vertical retort process is the cheapest among them.

\section{1. 緒言}

亜鉛の乾式製鍊に执いて画期的進歩を示した立型蒸溜 法は1929年米国で工業化に成功したが，長く水平蒸溜法 を稼㣫してきた三池製煉所では早くよりその原理に着目 し, 昭和15年より立型蒸溜ならびに亜鉛精溜に関する中 試験を長期にわたり実施し, 本法の技術的優秀性を確認 するとともに，国内亜鉛鉱および石炭を原料とする場合 の操業上の諸条件を解明した。

亜鉛蒸溜法の近代化については昭和25年欧 米の製錬所を調査したが，水平蒸溜工場では 米国におけるレトルト素地の真空混練および 調湿によるレトルトの迅速乾燥, 燃料源の天 然ガス，重油一の転換，ベルギーにおけける詰 替時の炉熱低下防止等のほかとくに見るべき ものなく，他方立型蒸溜法は漸次成績向上し てその製鍊費は水平法より相当低廉なること が確認され，ついに立型法の起業化を決定す るに至り，昭和27年工場建設に着手し同29年 1.月操業を開始した。

\section{2. 各種要鉛製鍊法の比較考察}

Walther Hänig ${ }^{1)}$ は立型蒸溜法と他の亜鉛製鋉法と

* 昭和 35 年 4 月 19 日受理

** 三茾金属釷業株式会社神岡鉣業所技斾長
の比較考察を試み, 水平レトルト法は有利な前提で競争 にたえ得る限りその役割はまだ終了していないが，新製 鍊所の建設には全然問題とならず，覀鉊製鍊の指導的役 割を電解法と立型蒸溜法に譲りつつあると発表した。

各種製鍊法を比較するに当つては工場の立地条件が前! 提となり, 電源地帯では電解法, 炭田地域では乾式法が 有利なことは論をまたないが，その工程，原単位，製鍊 費などの比較を第 1 表および第 2 表に示す。

第 1 衣工程原単位などの比較

\begin{tabular}{|c|c|c|c|c|}
\hline 摘 & 水 平 法 & 立 型 法 & 電 熱 法 & 法. \\
\hline 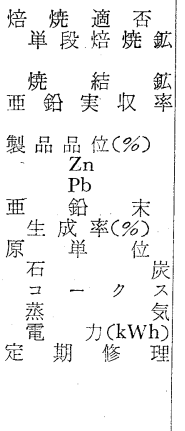 & 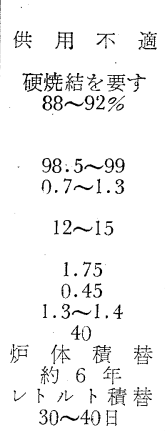 & 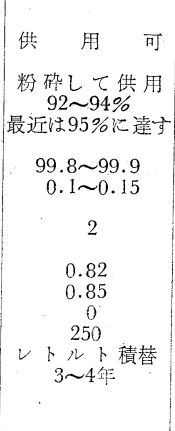 & 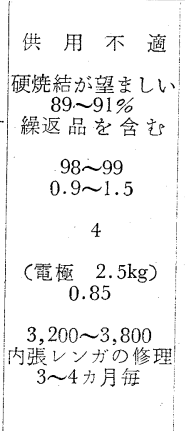 & 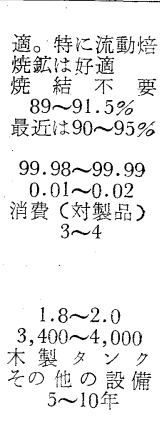 \\
\hline
\end{tabular}

米国調査の結果によれば，水平蒸溜工場の製錬費はそ の生産規模, 立地条件, 天然ガス利用の可否等により著 しく異なり, 当時米国においてポンド当り最低 3.1 セン 


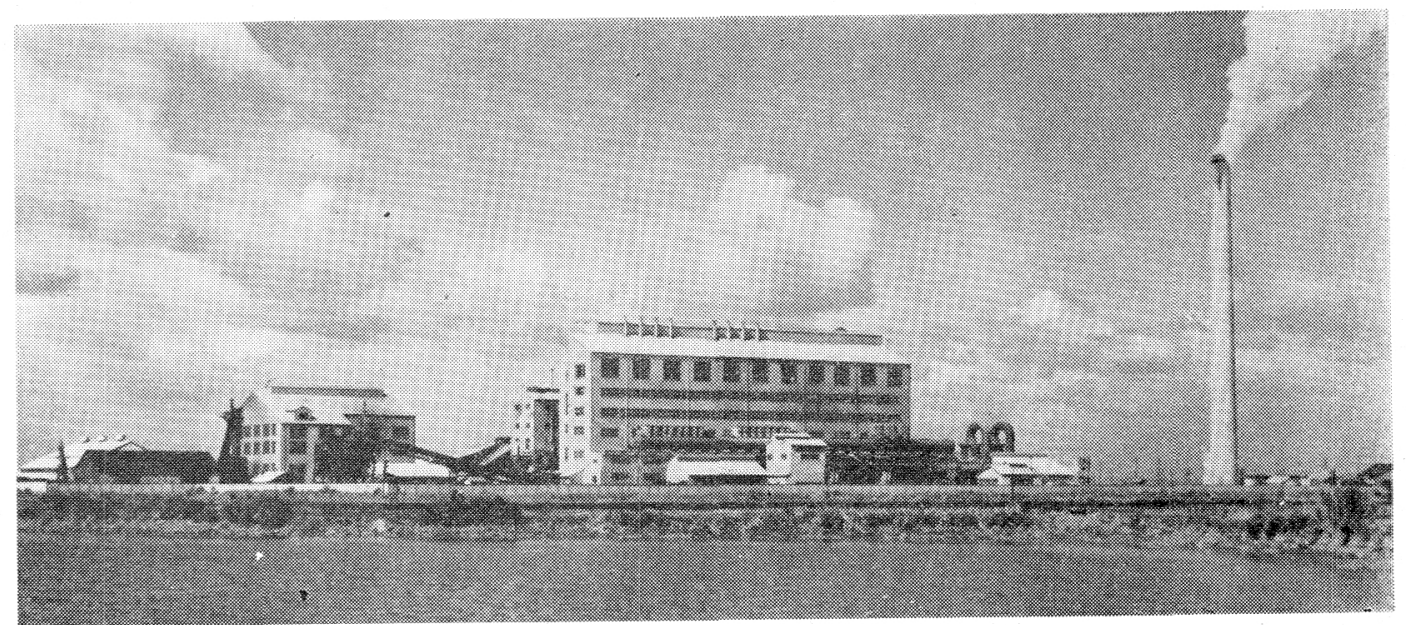

第1図新讙立型蒸溜亚鉛工場

第2表 米国に和ける製鍊費比較

(単位 $c / l b$ )

\begin{tabular}{|c|c|c|c|}
\hline 摘 & 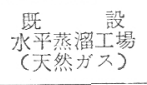 & 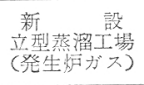 & $\begin{array}{c}\text { 既 設 } \\
\text { 恶釦電解工場 } \\
\text { Corpos Cbristi }\end{array}$ \\
\hline 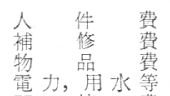 & $\begin{array}{l}2.03 \\
0.80 \\
0.93 \\
0.05\end{array}$ & $\begin{array}{l}1.30 \\
0.44 \\
0.52 \\
0.21\end{array}$ & $\begin{array}{l}1.67 \\
0.37 \\
0.92 \\
0.66\end{array}$ \\
\hline 間償却妾含む) & 0.09 & 0.98 & 0.15 \\
\hline 製鍊費 計 & 3.90 & 3.45 & 3.75 \\
\hline
\end{tabular}

ト, 最高 4.8 セントと称せられていた。さらに建設費党 考慮に入れると, 立型法は建設費はもつとも高いが操業 費はもつとも安く, 電熱法は建設費は安いが操業費は高 々，電解法注両者の中間に位すると言われた。

以上 4 種の製鍊法の他にドイツ Duisburg 銅製鍊所で 研究せられたアマルガム電解法がある。本法は複雑釯上 り $99.999 \%$ 亚鉛を製造するもので，ドイッで戦時中年産 $10,000 t$, 起業費 12,000,000 マルク，アマルガム電解槽 65 組，テイントン電解槽 5 槽で計画されたが，水銀損失 による経費高, 副生塩素の取扱い等に問題があり, また その製品业鉛は高純度品位なるも $0.0002 \%$ の水銀圭含有 乙て加工性を阻害する懸念㐫り, 本法は今後発展するも のと考えられなかつた。

1957年, 英国 National Smelting Co.より発表され た愹鉙炉による覀鉊製鍊はその発展を注目されている が，当時は技術的にも相当困難視されていた。

\section{3. 中試験の経過}

\section{$3 \cdot 1$ 三池中試験}

水平レトルトを縦にして装入排出の機械化を図るいわ ゆるニイツハイム法類似の研究はすでに昭和 11 年着手 乙,さらに昭和 15 年より亜鉛精溜炉および立型蒸溜炉を
三池独自の設計に基ずき築造して中試験定実施した。 立型中試験炉 1 基 レトルト寸法 (内法) $1,130 \times 340 \times 4,475$

有効加熱面積 $10 \mathrm{~m}^{2}$

レトルトは国産炭化珪素サンドによる自家製レンガを 使用したため、レンガの炭化珪素純分は75\%前後のいわ ゆるセミ・カーボレンガにして，それ自体の分解に基ず くレンガの崩壞, 目地の脱落といら困難に遭遇したが, 次等に熟練するにしたがい成績も向上し，好調時は脱两 率96\%，西鉛実收率 $90.5 \%$ の成績を得て立型法の優秀性 を確認した。なおこの中試験によつて立型レトルト内に 操業中に発生する種々の現象を解明することができた。

\section{$3 \cdot 2$ 米国中試験}

1950 年 9 月より約 3 力月間, 米国 New Jersey 州 Netcong にある Singmaster 社の試験工場において， 神岡典鉛鉱および三池炭による製団炭化蒸溜の一連の中 試験安実施した。その試験設備は次のよらであつた。

立型レトルト 1 基 長 $59^{\prime \prime}$ 幅 $12^{\prime \prime}$

加熱高 $16^{\prime}$ 有効加熱面積 $165 \mathrm{ft}^{2}$

重油加熱 オイルバーナ一位置 燃燒室天井 立型コーカー 1 基 $5^{\prime} 93 / 4^{\prime \prime} \times 131 / 2^{\prime \prime}$ 幅 $14^{\prime \prime} \rightarrow$ $21^{\prime \prime}$

格子面積 $4.5 \mathrm{ft}^{2}$ 格子空償率 $34 \%$

この中試験に㧍いて「神岡鉙・三池炭」の組合せによ る団鉱の炭化蒸溜の最適条件を決定するとともに, な拀 つぎの諸点が明らかになつた。

（1）上昇気流確保 脱亜促進のためにレトルト底部 に空気を導入することは，炬底にて局部的に愹鉣炉反応 を生じ, 灰の愹融点の低、三池炭老愹融せしめクリンカ 一大塊の生成を促し, 鉣滓排出の困難さらに炉鉄生成の 原因となる。よつて酸素を含まないガスであることが絶 対条件で，これには燃焼室廃ガ大が充分役立つ。 
(a)

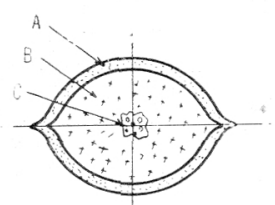

(b)

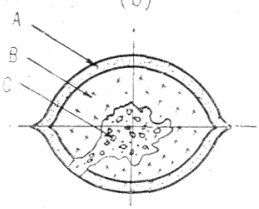

第2図 Netcong 中試験炭化団鉣

（2）鉱㩐強度江無煙炭全部定三池コークス微粉で置 換した団鉱が最強で完全脱覀するも鉣滓は崩壞しない。

(3) 炭化首はレトルト内でカラミ化作用を促進す b。

第2困に示したのが Netcong 中試験炭化団鉝の断面 図で図中の記号は次のようである。
(a) 良好な炭化団鋝
（b）不良な炭化団鉱
A. 表皮。平均 $2 \mathrm{~mm}$
A. 表皮。厚さは条件次
厚, 時に $\mathrm{ZnO}$ の
薄層で覆われ一部 第で広範囲に変る。
灰白色怘呈す。
B. 緻密強固な炭化構 造。金属光沢に近 w。
C. 中心径 5 10mm 多孔質。紫黒色在 呈す。
B．炭化構造。乙ばしば 無定形炭素孛析出す る。
C. 中心部海綿状構造で 軟弱。
タール質表面へ貲 出。

\section{4. 三池工場設計の基本と特長}

立型蒸溜工場の設計は, 本法発明当初にあつてはその 当時建設されたレトルトに見られるごとくなお多くの不 都合な点があつた。たとえば Meadowbrook では鉣滓 排出口を回転テーブルでドライシールの形としたため, 炉底から空気が自由に流入しやすくその量它調節するこ こが困難であつた。ドイッ Oker ではコーカーの前に 高熱排風機を設置したためこれが操業のもつとも重大な 障害となつた。

本法溌明以来すでに20数年老経過して設計も相当に 進歩し，とくに最近米 Palmerton およざ仏Auby で建 設した炉はレトルトの高さが従来の $25 \mathrm{ft}$ から $35 \mathrm{ft}$ 人 延長され，レトルトの単位容量も約 2 倍近く増大したと 報ぜられている。コーカーは立型から傾斜型へと進み， コンデンサーも種々の改良型が試みられた。

\section{$4 \cdot 1$ 三池立型炉設計の特長}

三池立炉設計の基本は技術的に試験済の標準型を採用

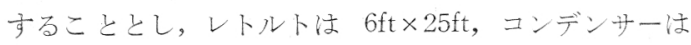
バッフル型，コーカーは立型直接式を採用することとし たが，そのほかに次の3 点が世界における立型設計の最
初の試みとして大きな特長を有する。

（1）レトルト締付に圧縮バネ妾適用する。

（2）上方延長部はレトルトと分離し別箇の鋼材にて 支持する。

（3）㨙熱室はア一ムコ方式老採用し，かつ燃焼室上 分離して炉体在独立させる。

以上がレトルト設計の基本でこのため在来のレトルト に比較し著しく変化交きたしたが，さらに第2 期増設工 事の際はレトルト掃除口，鉣流搬出機，廃ガス泠却法な どに三池独自の方式安採用した。その結果第 2 期レトル 卜は操羑開始と同時に亜鉛採収率 $94 \%$ に達し, その後る 長期におよび好成績を維持した。設計の基本となつた問 題点法つぎの通りである。

\section{$4 \cdot 2$ 工場配置}

三池の設計に执いては第3 図に示すと㧍り，粉砕，調 合，蒸溜，ガスの4工場分分離独立させ，さらに排風機

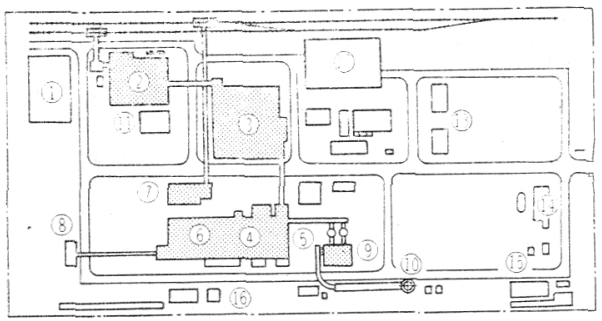

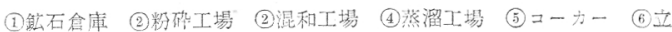

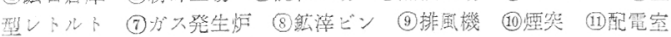

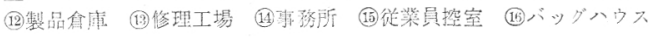

第3 図 立型蒸溜工場配置図

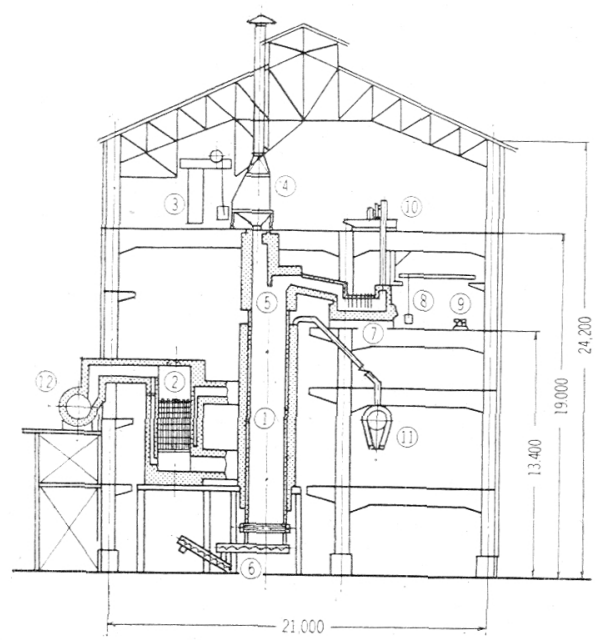

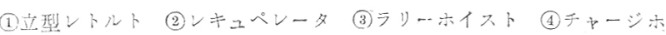
ッパー (5)アッパーエタステンション (6)スタリュー排出模 (7)コンデ ンサー (8)レードル (9)モールドスタンド (10Obnoxious Vapor Condenser (11)プロデューサーガス道 (12)ウェストガス道

第4図蒸溜工場断面図 


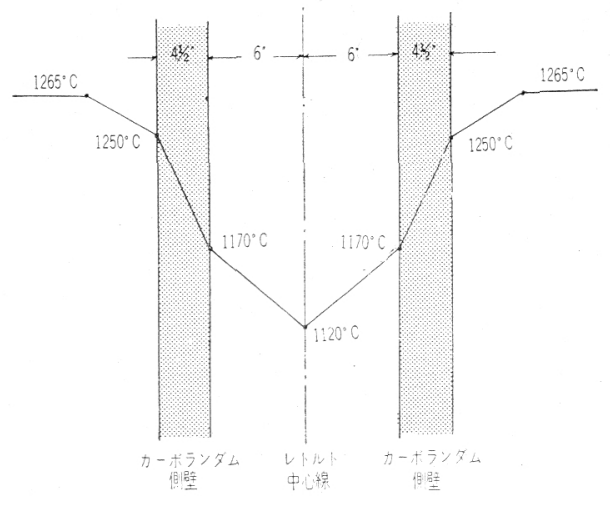

第5图レトルト断面熱伝達図

至, 配電室などを独立させ，かつ将来昖張が容易に実施 乙得名配置とした。

\section{$4 \cdot 3$ レトルト棈造}

レトルトは技術的にもつとも安定した䅺準型を採用す ることとしたが，レトルト下部の水套構造を廃止してレ ンガ積構造としたため, カーボランダムレンガの段数は 増加して炉にお汀る総段数 165 段, 総高 $35 \mathrm{ft}$ となつた。 第 4 図に蒸溜工場断面，第 5 図にレトルト断面熱伝達図 交示す。

\section{4レトルト締付法}

レトルトの 4 つの壁は自由に膨镺收縮し得るように滑 り接手を構成し端壁に充分の染さの满を形成して，その 中に側壁が嵌合らようにし，この端壁にスタッフィング ・ボックスを作りこれにカーボランダム粉末を充填して 自由膨脤老許容するとともに蒸気気密を保持する構造が 従来の方法であつた。

しかしこの構造はレトルト乾燥中に発生する初期龟裂 を防止するには充分でなくまた長期にわたり蒸気ガス 気密を保持することに多くの困難がある。レトルト壁の 亀裂ないし目地開きは垂直目地に発生し, これが順次発 達して行くもので，水平目地にはほとんど発生しないこ とが筆者の中試験においても実証された。このため圧縮 バネを使用するレトルト締付法が考案されたが2, 今回 三池炉の設計に执いて初めて本法在工業的に採用寸るこ ととした。その結果は良好で初期龟裂老完全に防止し得 たのみならず，側壁の異常膨非による端壁付近のヒズミ 龟裂を防止し，第1期レトルトにしてすでに 3 年以上の 長期寿命を確保することができた。第6図にレトルト締 付断面を示す。

\section{5。三池炭の特質とその配合}

\section{$5 \cdot 1$ 団鉱製造の要点}

立型蒸溜用団鉱製造に打いてとくに重要なことは蒸溜 残澏の強度が充分高く，西鉛を溜出し去つた後もその残

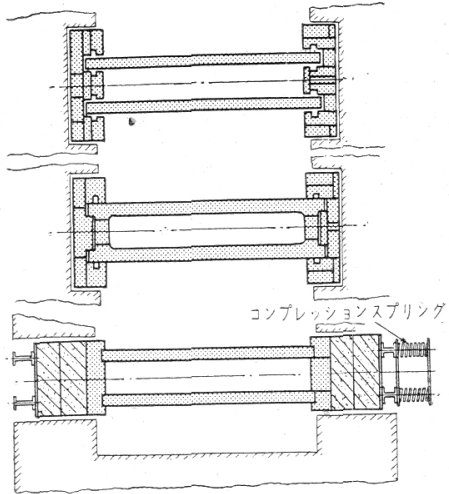

第6图レトルト締付断面図

㵏が崩壞することなく団鉱の原形坴保持して，重力によ りレトルト内無事下降し終ることである。団鉱は脱亜 が進行するにしたがい多孔性となり強度は次第に弱くな り崩壤粉化し易くなる。レトルト内で崩壊すると中途に おいて䀣垂あるいは閉塞老惹起し装入排出作業は不可能 となるに至る。この残涳強度を保持するために㱙残㳯中 に亜鉛を4〜6\%程度残留させるのが普通であるが，強度 が高いとさらに脱䀯を進行せしめることができる。

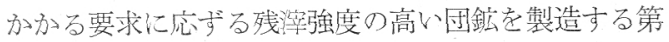
一の要点は適正なる粘結炭の選択配合である。三池炭は 下記のような異常な特質を有しコータス製造の際も三池 炭単独にて製造したコータスはその潰裂強度が低く，か つ粉コークスの生成率高く，したがつてまた三池炭配合 の亜鉛団鉣も全く同様な現象老呈するので，その団鉣の コーキングの条件設定が難かしい。

\section{$5 \cdot 2$ 三池炭の特質}

(1) 強粘結である。カンブレドン粘結率 30.7

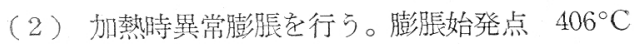
膨䐘終止点 $450^{\circ} \mathrm{C}$ 容積膨脹率 約 400 倍

（3）灰分の愹融点が著しく低い。1,050 $1,100^{\circ} \mathrm{C}$

（4）硫黄の含有量が非常に高い。 $\mathrm{S}=3.5 \sim 4.4 \%$

(5) $\gamma$ 化合物が多く $\beta$ 化合物の約 1.5 倍を含有寸る。

（6）揮発分はメタン等の重炭化水素が多い。

亜鉛の炭化団鉱莸製造する場合はコークス製造の原理 と大体類似しているが，歴青粘結炭単独では不可で一定 量の非粘結炭とくに無煙炭の配合老必要とすることが明 らかにされた。

\section{3 配合炭亡団鉱強度}

まず還元用として配合する不炭の選定と乞の配合比の 研究に主力老注ざ, 粘結炭としては三池のほかに鹿町, 高島，美唄等また無洷炭として天草，田川，大領，䲨基 の各種について多くの試験を行つた結果，次の配合がレ トルト内で骭猿せず原形のまま排出され得る残滓強度を 有することを見出した。各種石炭を配合せる団鉱ならび 
飞蒸溜鉱滓の強度を第 4 表汇示す。

第3 表 基準配合表

\begin{tabular}{|c|c|c|c|c|c|}
\hline 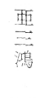 & $\begin{array}{l}\text { 鐎 } \\
\text { 渵 }\end{array}$ & 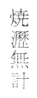 & $\begin{array}{l}\text { 結 } \\
\text { 湆 } \\
\text { 湮 }\end{array}$ & 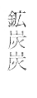 & $\begin{array}{r}60 \\
32 \\
8 \\
100\end{array}$ \\
\hline
\end{tabular}

第 4 表 配合炭々団鎕強度

\begin{tabular}{|c|c|c|c|}
\hline 成 & 三 池 崖 & 亮島崖 & 麼町宸 \\
\hline 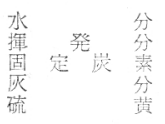 & $\begin{array}{r}1.29 \\
38.75 \\
40.98 \\
19.00 \\
3.22\end{array}$ & $\begin{array}{r}1.20 \\
37.92 \\
42.96 \\
17.66 \\
0.60\end{array}$ & $\begin{array}{r}1.46 \\
21.94 \\
51.90 \\
25.16 \\
0.67\end{array}$ \\
\hline 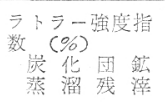 & $\begin{array}{l}89.0 \\
51.0\end{array}$ & $\begin{array}{l}81.5 \\
19.5\end{array}$ & $\begin{array}{l}62.0 \\
10.5\end{array}$ \\
\hline
\end{tabular}

本邦無煙炭の配合はいず扎も強度低くレトルト内で塴 壞し，鴻基無煙炭のみが立型炉装入に必要な強度を示し たが，こ机は企業化の場合輸入点注もち万几採算的に も好ましくない。よって炭化団鉱生成の機構を研究し， 無煙炭の代りに全部 80 mesh 以下の微粉コークスを添 加して, 団鉱の骨格を形成する部分の気孔を充埧し緻密 化することにより強度が著しく増大されることを見出し た。この方法により製造した炭化団鉱の強度は現在米国 New Jersey Zinc Co. で使用中の Connellsville 崖配 合のPalmerton の団鉣よりも強度が大であり，このこ 々が三池の立型蒸溜が操業当初から欧米のそれより好成 績を㐫げ得た主原因上考えられる。

\section{6. 操業系統説明}

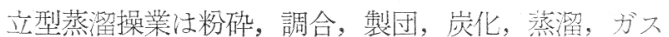
の6段階に区分することができる。第7図にその操業系 統図宗示。

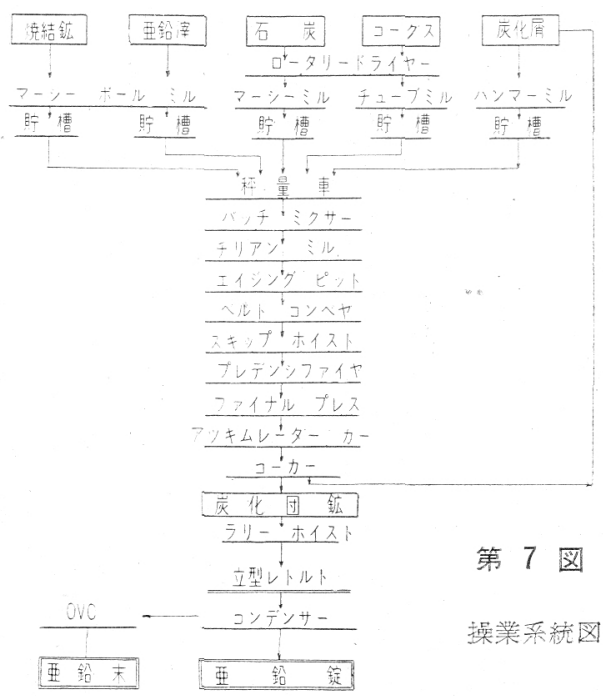

\section{$6 \cdot 1$ 粉砕}

亜鉛原料は大部分焼結鉱老使用し，また产の時の鉱石

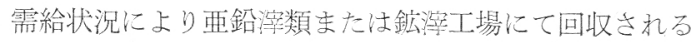
酸化亚鉛類索使用する。これらはいずれもマーシー型ボ 一ルミルにて粉砵後 32 mesh の振動フルイにてフルイ分 けて調合工場貯樯汇送る。石炭およびニークスは回転畭 燥機至通乙て水分 $2 \%$ 以下に乾燥する。

\section{$6 \cdot 2$ 調合}

各種原料粉砕物の貯槽として鉄板製角型貯槽10個を有 し，兑の下を科量車が走り 1 回 2.5 tの回分科量を行う。 最近団鉣強度および脱两成績を低下させることなしに還 元片を隇少することに成功し，その配合を第 5 表に示 すように変更した。

第5表 調 合 割 合

\begin{tabular}{|c|c|c|c|c|c|}
\hline 原 & 材 & 料 & 29年 1 月以降 & 33年 1 月以俻 & 35 年 1 月以嚾 \\
\hline $\begin{array}{l}\text { 严 } \\
\text { 石 }\end{array}$ & $\begin{array}{l}\text { 鈛 原 } \\
\text { - 部 }\end{array}$ & $\begin{array}{l}\text { 料 } \\
\text { 荹 } \\
\text { ス }\end{array}$ & $\begin{array}{r}100 \\
55 \\
15 \\
170\end{array}$ & $\begin{array}{r}100 \\
47.3 \\
10.2 \\
157.5\end{array}$ & $\begin{array}{r}100 \\
49.3 \\
8.2 \\
157.5\end{array}$ \\
\hline
\end{tabular}

科量車にて所定比率に称量された各原料は，次の混和 機を経て大型チリアンミルに入り，ここでバインダーの 亜硫酸廃液老添加儿, 混練を行い, 混練物柱中央排出孔 加らコンベヤにてエイジングピット纪運ぶ。

\section{$6 \cdot 3$ 製団}

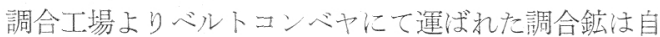
動スキップホイストにて約 $23 \mathrm{~m} の$ 高所に揚价られ貯槽に 大り，これよりパッドルミキサーを経てつぎの 2 系列の 製団装置化入る。

$$
\begin{aligned}
& \text { プレデンシファイヤー 佳 } 560 \times \text { 幅 } 220 \mathrm{~mm} \\
& \text { ポケット 4列 } \times 34 \text { 箇=136簀 } \\
& \text { フォイナルプレス 径 } 560 \times \text { 幅 } 220 \mathrm{~mm} \\
& \text { ポケット } 2 \text { 列 } \times 24 \text { 筒 }=48 \text { 筒 }
\end{aligned}
$$

団鉱小法 $105 \times 73 \times 50 \mathrm{~mm}$

団鉱重量 4 団鉣 $600 \mathrm{~g}$ 炭化団鋕 $490 \mathrm{~g}$ $6 \cdot 4$ コーキンク

ファイナルプレス教た生団鉱はアッキムレイタカー

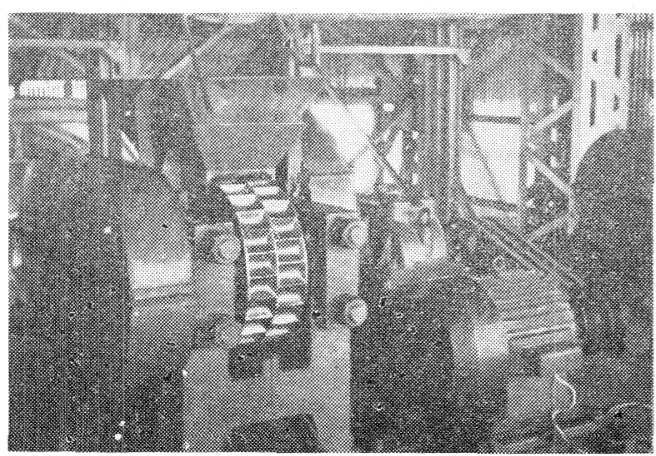

第8図団鉱機 
によつて直ちに立型コーカーに供給され, 高熱ガスの直 接気流に曝され水分ならびに石炭中の揮発分追、出 乙, 多孔質の炭化団鉱となる。この高熱ガスに蒸溜炉 の燃燒排ガス在利用し，こ机はレキニペレータ一からレ ンガ内張鉄製煙道を経てコーカーに大る。

\section{5 蒸溜}

立型レトルト 4 本 2 基 計 8 本 レトルト (内法) 幅 $305 \times$ 長 $1,905 \mathrm{~mm}$ 有効加熱高 $7,337 \mathrm{~mm}$

カーボランダムレンカ積 165 枚 総高 $10,750 \mathrm{~mm}$ 有效加熱面積 $28 \mathrm{~m}^{2}$

レトルト外側はそれぞ机燃焼室上なり，発生炉ガスは 燃燒室天井汇設けた 4 個のガスバーナーから下方に噴出 し，空気はレキュペレーターにて予熱後燃焼室側壁に 5 段のレベルに 4 箇ずつ設けた計 20 简の空気ポート上り燃 燒室に入り，レトルトを $1,250 \sim 1,260^{\circ} \mathrm{C}$ に加熱する。 亜鉛蒸気はコンデンサーにて凝縮し，これは一定時間ご とにレードルに波出し $20 \mathrm{~kg}$ 型比鋳造する。

\section{$6 \cdot 6$ ガス}

立型レトルト 8 本操業に詨し発生炉 2 基常時運転々 几, 発生炉は60分に1回の割で投炭を行い，之の灰分は 下部の回転皿から連続的に排出さ机る。発生炉力゙ス法茾 イクロン抒よびバルーン煙道を通り燃焼室頂部のバーナ ーに入る。燃焼廃ガスは炉底よりコネタターを経てレキ ニペレーターに大り, 燃燒用空気索予熱㣪共通煙道加ら コーカーに行く。コーカ一廃力゙ス注洗浄塔にて洗浄泠却 後排風機を経て煙突に排出さ礼る。

\section{7. 建設工事概要}

建設工事は第 1 期 4 炉，第 2 期 4 炉飞分けて実施した が，粉砾調合工場はほとんど第 1 期汇工事完了しかつこ れは将来の拡張老見込み稼衝時間の延長のみにて16炉分 ないし18炉分在充分処理し得る能力とした。之の工事概 要老以下に示す。

工場敷地総面積 12,000 坪

主 要 建 家 粉砵工場, 調合工場, 蒸溜工場, 出

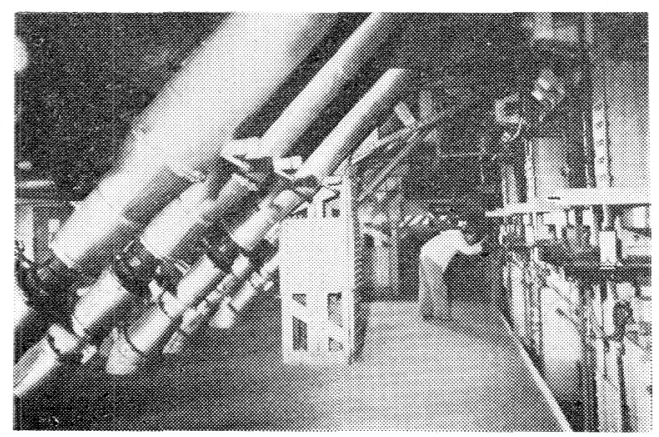

第 9 図蒸溜炬前面
又工場 各 1 棟

主 要 設 備 立型蒸溜炉, 第1期 4 レトルト

第 2 期 4 レトルト

$\begin{array}{llll}\text { ガス発生炉 } & 3 \text { 基 コーカー } & 2 \text { 基 } \\ \text { チニイサー } & 3 \text { 台 製団機 } & 2 \text { 系列 }\end{array}$

第6 表 建設資材表

\begin{tabular}{|c|c|c|c|c|}
\hline$I \$$ & 材 & 第 1 期 & 第 2 期 & 全 \\
\hline 土致工事 & 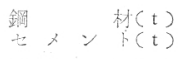 & $\begin{array}{l}2,588 \\
3,120\end{array}$ & $\begin{array}{r}1,100 \\
550\end{array}$ & $\begin{array}{l}3,688 \\
3,670\end{array}$ \\
\hline 機珹工求 & 主要機椷 $(t)$ & 1,688 & 810 & 2,498 \\
\hline 笔聂,工事 & 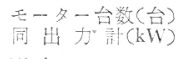 & $\begin{array}{r}156 \\
1,779\end{array}$ & $\begin{array}{r}65 \\
841\end{array}$ & $\begin{array}{r}221 \\
2,620\end{array}$ \\
\hline 築炉工事 & 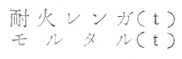 & $\begin{array}{r}1,440 \\
171\end{array}$ & $\begin{array}{r}1,074 \\
141\end{array}$ & $\begin{array}{r}2,514 \\
312\end{array}$ \\
\hline 計測工而 & 人-夕一台数(台) & 94 & 80 & 174 \\
\hline
\end{tabular}

\section{$7 \cdot 1$ カーーボランダム・レトルト}

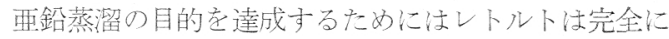
気密であること老要し，その気密の度合注従来のガ炉 や骸炭炉より遙か汇蕨重である。立型レトルトは多数の レンガを僅が一枚厚にて積上げて築造し，それが高熱 状態で気密を保持して亜鉛蒸気の通過するレトルト内部 と燃燒ガスの通過する外側を完全に遮断するため注次 の諸点が肝要である。

（1）各段レンガの厚さの完全な均一。厚さ41/2inに 対し許容士 $1 / 32$ in, 実際筑炉の際は各面の替合せを行 $5 。$

(2) 側壁は内外両面に炭化珪素嬏薬定塗布する。

（3）均一加熱。とくに築炉後の乾燥昇温にお沙る温 度分布の均一。

立型レトルト築造用レンガとしては種々の耐火物が考 えられたが、これに必要な諸性質たとえば熱伝導度, 熱 間荷重, 耐蝕性などから判断して炭化珪素レンガが今日 使用乙得る唯一の材料であり，また炭化珠素レンガの優 秀品の製造が立型レトル下法を成功させたと言い得る。

米独の代表的レンガの諸性質老第7 表佂示す。

第 7 表 茂化珪素レンガの比較

\begin{tabular}{|c|c|c|c|}
\hline & \multicolumn{2}{|c|}{ * Carborundum * } & \multirow{2}{*}{$\begin{array}{c}\text { 独 Didier 社 } \\
\text { Carsial } O\end{array}$} \\
\hline & Carbofrax & Refrax & \\
\hline 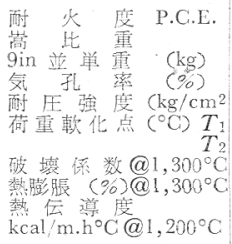 & $\begin{array}{c}38 \\
2.57 \\
4.20 \\
13.2 \\
1,070 \\
1,345 \\
1,505 \\
2,000 \\
0.53 \\
9.6\end{array}$ & $\begin{array}{r}38+ \\
2.87 \\
4.67 \\
7.9 \\
1,380 \\
>2,000 \\
5,640 \\
0.53 \\
10.0\end{array}$ & $\begin{array}{r}\mathrm{SK} 40 \\
2.81 \\
4.59 \\
12.6 \\
1,850 \\
1,545 \\
1,570 \\
\\
0.60 \\
9.7\end{array}$ \\
\hline $\begin{array}{ll}\text { 分析值 } & \mathrm{SiC} \\
& \mathrm{SiO}_{2} \\
& \mathrm{Si}_{3} \mathrm{~N}_{4} \\
& \mathrm{Al}_{2} \mathrm{O}_{3} \\
& \mathrm{Fe}_{2} \mathrm{O}_{3}\end{array}$ & $\begin{array}{r}89.16 \\
7.72 \\
0.35 \\
0.87\end{array}$ & $\begin{array}{r}76.42 \\
7.24 \\
12.38 \\
0.57 \\
0.68\end{array}$ & $\begin{array}{r}90.21 \\
7.30 \\
1.90 \\
0.70\end{array}$ \\
\hline
\end{tabular}

\section{$7 \cdot 2$ レキュペレーター}

蒸溜炉燃焼室に連結するレキニペレーターの構造はレ 


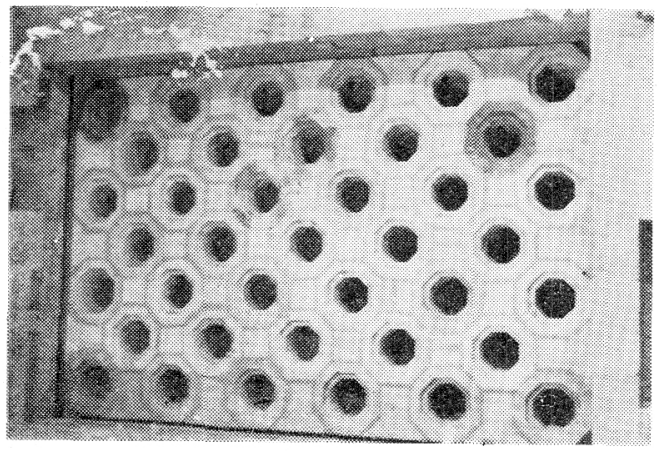

第10図レキュペレーター

トルトの構造と同様に重要である。その熱交換効率法燃 料原単位を直接左右し、さらに气の耐久如何, 漏溲の有 無沈炉の操作汇大きな影響老及代すからである。レキニ ペレーターとして漏洩の無いこと, 掃除の容易なこ々, 熱交換効率の高いことなどの要求以外に, その廃ガス在 さらにコーキングに利用するための多くの制約がある。

筆者の中試験では筆者自身の設計になる水平煙道型を 選んだためにとの煙道掃除に非常な困難を経験し, 欧米 の既設工場でもレキニペレータ一掃除に多くの障害在見 出したので，三池設計では廃ガス煙道を垂直にすること を第一の前提として，米国 AMCO 社特許のレキニペレ ーターを初就て立型炉化採用することに決定した。

この型法八角形チニーブを多数積上げ，廃ガス泣于= 一ブ内垂直に上昇し，空気はチニーブの外側をジグザ グに下降し，高熱に予熱せられて燃焼室に入る。关の構 造学10図俰示。

(1) 設計の基本

八角管 内径 $4 \mathrm{r} / 2 \mathrm{in}$ 壁厚 $1 / 2 \mathrm{in}$ 高 $11 \%$ in 有効伝熱面積 1 本当 $0.1125 \mathrm{~m}^{2}$ 廃ガス通過面積 1 本当 $0.0099 \mathrm{~m}^{2}$

1段の配列39本1炉 2 室に付 78 本

1 炉分廃ガス通過面積 $0.7722 \mathrm{~m}^{2}$

$$
\text { "廃ガス流量 } 1,935 \quad \mathrm{~N} \text {-CMH }
$$

段数 8 段の伝熱面積 $\quad 70.2 \mathrm{~m}^{2}$

次記計算から $67.1 \mathrm{~m}^{2}$ あればたりるので八角管の積上 段数法 8 段とする。

(2) 所要伝熱面積計算

Heiligenstaedt $\emptyset$ 方程式 $\left.{ }^{3}\right)$ によ秃ば

$$
\begin{gathered}
G^{\prime} C_{D^{\prime}}\left(v_{1}^{\prime}-v_{2}^{\prime}\right)=\eta \cdot K \cdot F \frac{\left(v_{1}-v_{1}^{\prime}\right)-\left(v_{2}-v_{2}^{\prime}\right)}{\ln \frac{v_{1}-v_{1}^{\prime}}{v_{2}-v_{2}^{\prime}}} \\
Q=\eta \cdot K \cdot F \frac{\Delta v_{0}-\Delta v_{F}}{\ln \frac{\Delta v_{0}}{\Delta v_{F}}} .
\end{gathered}
$$

上式を簡単㲹するため係数 $n$ 党用いて算術平倧值に 置替える。

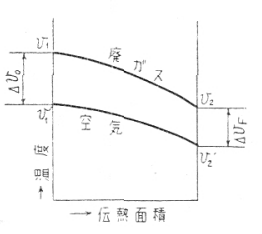

$$
\frac{\Delta v_{c}-\Delta v_{F}}{\ln \frac{\Delta v_{j}}{\Delta v_{F}}}=n\left(v_{m}-v_{m^{\prime}}\right)
$$$$
Q=\eta \cdot K \cdot F \cdot n\left(v_{m}-v^{\prime} m^{\prime}\right)
$$$$
K=\frac{1}{\frac{1}{\alpha}+\frac{1}{\alpha^{\prime}}+\frac{\delta}{2}}
$$

$F=$ 所要伝熱面積 $\mathrm{m}^{2}$

$Q=$ 総伝熱量 kcalih

$K=$ 総括伝熱係数 $\quad \mathrm{kcal} / \mathrm{m}^{2} \cdot \mathrm{h} \cdot{ }^{\circ} \mathrm{C}$

$\eta=$ 換 熱効率 \%

$G=カ 3$ 不流量 $1,935 \mathrm{~N}-\mathrm{m}^{3} / \mathrm{h}$

$G^{\prime}=$ 空気流量 $1,304 \mathrm{~N}-\mathrm{m}^{3} / \mathrm{h}$

$C_{p}=$ ガ ス比熱 $\mathrm{kcal} / \mathrm{m}^{3} \cdot{ }^{\circ} \mathrm{C}$

$C_{p^{\prime}}=$ 空気比熱 $\mathrm{kcal} / \mathrm{m}^{3} \cdot{ }^{\circ} \mathrm{C}$

$\alpha=$ ス上り壁への熱伀達 $\mathrm{kcal} / \mathrm{m}^{2} \cdot \mathrm{h} \cdot{ }^{\circ} \mathrm{C}$

$\alpha^{\prime}=$ 壁より空気への熱伝達 $\mathrm{kcal} / \mathrm{m}^{2} \cdot \mathrm{h} \cdot{ }^{\circ} \mathrm{C}$

$\delta$ 二八角管の壁厚 $\mathrm{m}$

$\lambda=$ 八角管の熱伝導度 $\mathrm{kcal} / \mathrm{m} \cdot \mathrm{h} \cdot{ }^{\circ} \mathrm{C}$

廃方不入口 $1,300^{\circ} \mathrm{C}$, 出口 $850^{\circ} \mathrm{C}$ 卞方場合, $20^{\circ} \mathrm{C}$ の空気学 $800^{\circ} \mathrm{C}$ 亿予熱するに必要な伝熱面積を求め礼 ザ次の通りである。

$Q=343,200-8,100=335,100 \mathrm{kcal} / \mathrm{h}$

ガス大口側 $K_{1}$ の計算

$$
K_{1}=\frac{1}{\frac{1}{39.81}+\frac{1}{19.73}+\frac{0.0127}{1.0}}=11.3
$$

ガス出口側 $K_{2}$ の計算

$$
\begin{aligned}
& K_{2}=\frac{-\frac{1}{22.93}+\frac{1}{22.84}+\frac{0.0127}{1.0}=10.0}{K=\frac{1}{2}\left(K_{1}+K_{2}\right)=\frac{1}{2}(11.30+10.0)=10.65} \\
& v_{m}-v_{m^{\prime}}=\frac{1,300+850}{2}-\frac{800+20}{2}=665 \\
& F=\frac{335,100}{0.90 \times 10.65 \times 0.98 \times 665}=53.7
\end{aligned}
$$

\begin{tabular}{|c|c|c|c|c|c|c|c|c|}
\hline 内 & & 容 & 指 & 示 & 記 & 绿 & 命 & it \\
\hline \multirow[t]{2}{*}{$\begin{array}{l}\text { 温 } \\
\text { 流 } \\
\text { 嶣 } \\
\text { 第 }\end{array}$} & 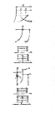 & \multirow[t]{2}{*}{ 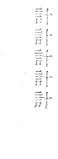 } & \multicolumn{2}{|l|}{$\begin{array}{r}6 \\
72 \\
58 \\
4 \\
0\end{array}$} & \multicolumn{2}{|l|}{$\begin{array}{r}18 \\
13 \\
10 \\
3 \\
1\end{array}$} & \multicolumn{2}{|l|}{$\begin{array}{r}24 \\
85 \\
69 \\
7 \\
1\end{array}$} \\
\hline & ht & & 140 & & 45 & & 185 & \\
\hline
\end{tabular}

以上に対し安全係数老 $80 \%$ 七す机ば

所要伀熱面積 $=53.7 \div 0.80=67.1 \mathrm{~m}^{2}$

\section{$7 \cdot 3$ 計測設備}

工場設計飞当つてはできる限り計測管理䘮可能ならし むるごとく多数の計測器を設置したがその配置数を第 8 表汇示す。

䈱 8 表, 計测器配 置 数 


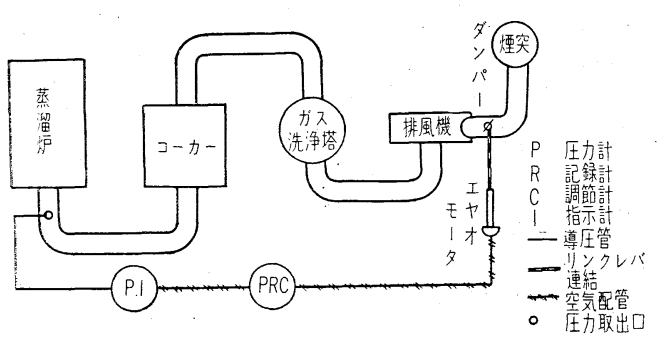

第11図 炉圧自動制御配憩図

刍動制御装置 温度 4 , 流量 1 , 圧力 3 , 計 8 以上のらち主なる計器は次の通りである。

(1) 炉温度記録計 Leeds \& Northrup Co. 炭化珪素製タンマン管を炉内に插入しこれからの輻射 線を鏡またはレンズにて絞り，Micromax Potentiometer に連結して記録する。感熱体としてクロメルーコン スタンタン製熱電対を放射線状に集中して直列に接続し たサーモパイルを使用する。

(2) 炉圧自動制御器 Minneapolis Honeywell Regulator Co.

レキニペレーター出口の共通煙道に通風検出端を設け ダブルベル型圧力計により検出し, その圧力検出值をト ランスミッターを通じ空気圧リレー機構にて約 $90 \mathrm{~m}$ 離れ た排風機室の調節計に送り，ダンバ一開度を自動的に調 節し蒸溜炉燃焼室通風の自動制御を行う。

\section{8. 操 業 成 績}

第 1 期建設 4 炉は昭和 29 年 1 月操業を開始したが，初 期に発生した各設備の故障や操業の困難を速やかに克 服し，従業者の熟練とあいまつて成績は次第に向上し， 数力月にして起業計画の想定成績に到達することができ た。さらに引続き増設した 4 炉は昭和 31 年 1 月操業開始 乙, ここに立型蒸溜 8 炉操業が実現爾来亜鉛月産 $1,000 \mathrm{t}$ 実収率 $92 \%$ 目標を遥かに上廻つた好成績を維持してい る。第 2 期 4 炉は第 1 期の経験を基としてさらに細部に

第 9 表 蒸溜操䍴条件

\begin{tabular}{|c|c|c|c|c|}
\hline 操業 条件 & 単 位 & $\begin{array}{c}\text { 初 期 操菜 } \\
\text { (29年 } 1 \text { 月以降 }\end{array}$ & 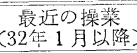 & $\begin{array}{l}\text { 大型レトルト } \\
\text { (35年 } 1 \text { 月以降) }\end{array}$ \\
\hline 墓 & $\mathrm{t} / \mathrm{\theta} / \mathrm{V}$ & 10.500 & 10.600 & 11.850 \\
\hline 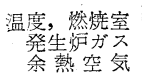 & $\begin{array}{l}{ }^{\circ} \mathrm{C} \\
17 \\
17\end{array}$ & $\begin{array}{c}1,270 \pm 10 \\
400 \\
650 \pm 50\end{array}$ & $\begin{array}{c}1,250 \pm 10 \\
400 \\
1,000 \pm 50\end{array}$ & $\begin{array}{c}1,250 \sim 1,260 \\
500 \\
1,000 \sim 1,050\end{array}$ \\
\hline
\end{tabular}

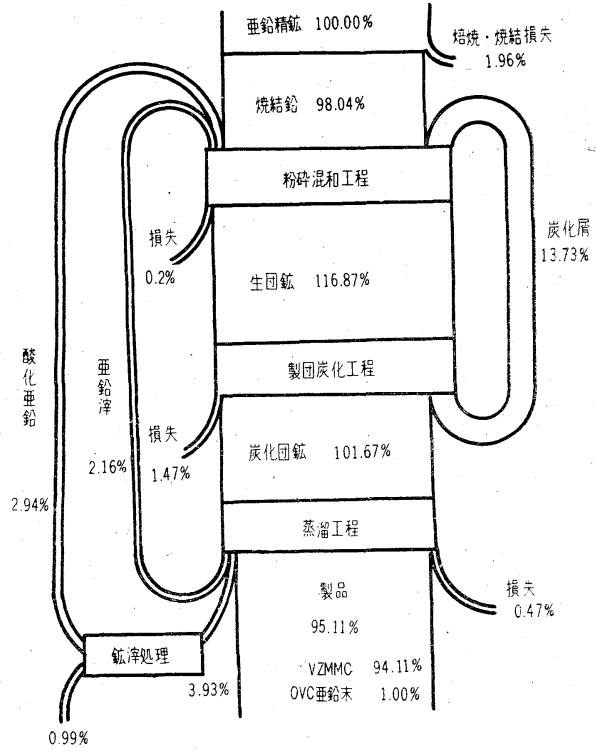

第12図 ジンクパランス

わたり改善を実施した結果，亜鉛実收率 $94 \%$ 示すに至 り，最近改築の大型炉では95\%を実現した。

以下の各表に操業条件, 生産状況推移その他の実績值 を示す。

第11表 三池亚鉛地金分析一例

\begin{tabular}{|c|c|c|c|c|}
\hline 成 & 分 & 立型蒸溜亜鉛 & 水平蒸溜严鉛 & 電気亚錻 \\
\hline & & 99.77 & 99.10 & 99.99 \\
\hline & & 0.162 & 0.77 & 0.0060 \\
\hline & & 0.050 & 0.123 & 0.0004 \\
\hline & & 0.0094 & 0.0055 & 0.0006 \\
\hline & & 0.0011 & 0.0005 & 0.0024 \\
\hline & & 0.0016 & 0.0004 & tr \\
\hline & & 0.0011 & 0.0031 & tr \\
\hline & & 0.0005 & 0.0023 & tr \\
\hline & & tr & 0.0006 & 0.0005 \\
\hline
\end{tabular}

第12表 立型蒸溜炉熱精算表

\begin{tabular}{|c|c|c|c|c|}
\hline & \multirow[b]{2}{*}{ 区 分 } & \multicolumn{2}{|c|}{33 年 2 月 測 定 } & 35 年 2 月測定 \\
\hline & & 熱 $\mathrm{kcal} / \mathrm{h} / \mathrm{R}^{\text {量 }}$ & 比 $\%$ & 比 $\%$ 率 \\
\hline 入 & 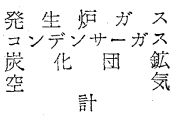 & $\begin{array}{r}580,272 \\
303,224 \\
100,100 \\
7,334 \\
1,260,930\end{array}$ & $\begin{array}{r}67.4 \\
24.1 \\
7.9 \\
0.6 \\
100.0\end{array}$ & $\begin{array}{r}61.7 \\
28.6 \\
9.2 \\
0.5 \\
100.0\end{array}$ \\
\hline 熱 & 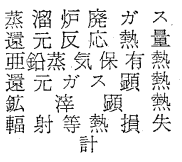 & $\begin{array}{r}564,834 \\
183,929 \\
130,232 \\
42,240 \\
39,285 \\
300,410 \\
1,260,930\end{array}$ & $\begin{array}{r}44.8 \\
14.6 \\
10.3 \\
3.4 \\
3.1 \\
23.8 \\
100.0\end{array}$ & $\begin{array}{r}39.8 \\
17.3 \\
12.3 \\
4.0 \\
3.7 \\
22.9 \\
100.0\end{array}$ \\
\hline
\end{tabular}

第 10 表 期 別操業 成績 推移

\begin{tabular}{|c|c|c|c|c|c|c|c|c|c|c|c|c|}
\hline \multirow{2}{*}{ 年 度 期 別 } & \multirow{2}{*}{28 年 } & \multirow{2}{*}{$\frac{29}{\text { 上 期 }}$} & \multirow{2}{*}{ 年 } & \multicolumn{2}{|l|}{30} & \multicolumn{2}{|l|}{31} & \multicolumn{2}{|l|}{32} & \multicolumn{2}{|l|}{33} & \multirow{2}{*}{$\begin{array}{l}34 \text { 年 } \\
\text { 上期 }\end{array}$} \\
\hline & & & & 上期 & 下 期 & 上期 & 下期 & 上期 & 下期 & 上 期 & 下期 & \\
\hline 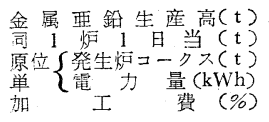 & $\begin{array}{r}975 \\
4.029 \\
1.045 \\
490 \\
100\end{array}$ & $\begin{array}{r}2,950 \\
4.144 \\
0.996 \\
428 \\
93.0\end{array}$ & $\begin{array}{r}3,091 \\
4.372 \\
0.927 \\
330 \\
80.8\end{array}$ & $\begin{array}{r}3,128 \\
4.393 \\
0.948 \\
313 \\
76.0\end{array}$ & $\begin{array}{r}4,577 \\
4.397 \\
0.962 \\
337 \\
73.2\end{array}$ & $\begin{array}{r}6,479 \\
4.553 \\
0.958 \\
312 \\
68.2\end{array}$ & $\begin{array}{r}5,717 \\
4.559 \\
0.953 \\
335 \\
71.0\end{array}$ & $\begin{array}{r}5,866 \\
4.656 \\
0.928 \\
300 \\
72.8\end{array}$ & $\begin{array}{r}6,688 \\
4.696 \\
0.888 \\
302 \\
73.3\end{array}$ & $\begin{array}{r}6,687 \\
4.670 \\
0.745 \\
267 \\
65.3\end{array}$ & $\begin{array}{r}6.633 \\
4.658 \\
0.708 \\
274 \\
63.7\end{array}$ & $\begin{array}{r}6,639 \\
4.642 \\
0.653 \\
244 \\
61.7\end{array}$ \\
\hline
\end{tabular}




\section{9. 鉱種別適性比較}

亜鉛精鉱の物理的化学的性質はその製鍊成績に支配的 影響を有するが，その影響の仕方は製錬方法の如何によ つてそれぞれ異なるものである。水平蒸溜の場合不純物 注充分注意を要し，とくにその含有 Fe 分がマーマタイ ト質の時は容器たる耐火粘土製レトルトを激しく侵蝕す る点でその影響は大きい。電解法では $\mathrm{Ni}, \mathrm{Co}, \mathrm{F}, \mathrm{Cl}$ ぞの不純物が多いと清浄が厄介である。

立型蒸溜では上記 2 方法に比して不純物の影響が極め て少ないのは注目に值するが，やはり $\mathrm{Fe}$ が10\%以上だ 々炉鉄を生成する傾向がある。また $\mathrm{Pb}$ が $\mathrm{PbS}$ として 存在する時は $\mathrm{SiC}$ を侵蝕して好ましくないがその他の 不純物はほとんど障害はない。

各種製鍊法に対する鉱種別適性比較の試験を行つたが 第13表に供用亜鉛精鉱の分析表, 第14表に適性比較の総 括を示す。

第13表 供用互鉛精鉱分析值

\begin{tabular}{|c|c|c|c|c|c|c|c|c|}
\hline 分 & 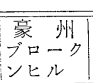 & 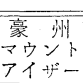 & {$\left[\begin{array}{cc}E & \text { 度 } \\
\text { ザワール }\end{array}\right.$} & $\begin{array}{l}\text { ビルマ } \\
\text { ボードゥ } \\
\text { イン }\end{array}$ & $\begin{array}{l}\text { 南 米 } \\
ヘ ゚ ル-~\end{array}$ & $\begin{array}{c}\text { イラン } \\
\text { カララ゙ン } \\
\text { 鉱 }\end{array}$ & 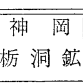 & $\begin{array}{l}\text { 福并基 } \\
\text { 中竟鉱 }\end{array}$ \\
\hline $\mathrm{Zn}$ & 51.30 & 50.10 & 53.25 & 54.35 & 57.18 & 52.60 & 60.0 & 52.1 \\
\hline $\mathrm{Fe}$ & $\begin{array}{l}31.30 \\
10.70\end{array}$ & $\begin{array}{r}0.10 \\
7.85\end{array}$ & 5.90 & $\begin{array}{r}3.80 \\
\end{array}$ & $\begin{array}{r}4.30 \\
4\end{array}$ & 7.65 & 3.4 & 10.1 \\
\hline $\mathrm{Pb}$ & 0.83 & 1.88 & $\begin{array}{l}1.52 \\
1.52\end{array}$ & 4.67 & $\begin{array}{l}1.94 \\
1.94\end{array}$ & 2.52 & 0.43 & 0.37 \\
\hline $\mathrm{Cu}$ & 0.10 & 0.15 & 0.05 & 0.17 & 0.63 & 0.02 & 0.08 & 0.12 \\
\hline $\mathrm{Cd}$ & 0.20 & 0.18 & 0.33 & 0.32 & 0.42 & 0.12 & 0.33 & 0.29 \\
\hline As & 0.07 & 0.02 & 0.05 & 0.21 & 0.25 & 0.29 & 0.01 & 0.01 \\
\hline Sn & & 0.002 & 0.0005 & 0.008 & $\operatorname{tr}$ & $\operatorname{tr}$ & - & \\
\hline $\mathrm{Sb}$ & 0.02 & 0.011 & 0.002 & 0.03 & 0.07 & 0.02 & $\operatorname{tr}$ & 0.01 \\
\hline $\mathrm{Bi}$ & t & 0.002 & tr & 0.01 & $\operatorname{tr}$ & $\operatorname{tr}$ & $\operatorname{tr}$ & 0.02 \\
\hline $\mathrm{Ni}$ & $\operatorname{tr}$ & tr & & 0.23 & $\operatorname{tr}$ & $\operatorname{tr}$ & & - \\
\hline Co & 0.015 & 0.006 & 0.007 & 0.04 & $\operatorname{tr}$ & tr & 0.02 & \\
\hline $\mathrm{SiO}_{2}$ & $\begin{array}{l}1.82 \\
1.82\end{array}$ & 3.35 & 2.43 & 2.25 & 0.94 & 7.10 & 1.60 & 1.41 \\
\hline $\mathrm{CaO}$ & 0.45 & 1.02 & 1.30 & $\operatorname{tr}$ & 0.25 & 3.40 & 0.59 & 0.30 \\
\hline $\mathrm{Al}_{2} \mathrm{O}_{3}$ & 0.1 & 0.87 & 0.17 & 0.56 & 0.15 & 1.80 & 0.08 & 0.22 \\
\hline $\mathrm{MnO}$ & 0.95 & 0.04 & 0.05 & 0.11 & 0.80 & 0.06 & 0.24 & 0.90 \\
\hline $\mathrm{MgO}$ & 0.54 & 0.62 & 1.17 & 0.15 & 0.06 & 0.97 & 0.09 & 0.13 \\
\hline (51 & 0.014 & 0.007 & 0.007 & tr & $\operatorname{tr}$ & & & \\
\hline S & 31.71 & 29.87 & 31.15 & 29.42 & 32.43 & 0.28 & 31.82 & 31.5 \\
\hline
\end{tabular}

\section{0. 今後の課 題}

三池の立型蒸溜工場は昭和 29 年 1 月その第 1 期 4 炉索 操業開始してよりすでに 6 年余を経過したが，その成績 を既述のように当初の計画值を上廻り，亜鉛実収率は水 平蒸溜法, 電解法または既設欧米立型工場の記録淩窵 し，とくに最近改修した炉は $95 \%$ 以上の実收率を示し， その製鋉費も大輻に低下した。

その理由としては長期の中試験による多くの新機軸を 設計に取入れ，その操業は三池独自の入念な方法を確立 したことにあるが，根本的には三池炭の特質たる強力な 粘結性を完全に活用したことに基因する。三池の団鉱鉙 滓の強度が立型工場の祖である Palmerton のそれるり も強く，その団鉱中の亜鉛老完全に溜出し去つてもレト ルト内で崩壊しないことは，好成績と高実収率を可能に した主要因子である。

以上の上うに三池の立型蒸溜炉は一応所期の成績安達 成したが, さらに今後の課題として研究す心゙き 諸点をあげれば次のとおりである。

\section{(1) レトルトレンガ}

立型レトルトにおける最近のもつとも重要な進 歩は窒化珪素を結合剤とする炭化珪 素レンガ REFRAX の採用で，Avonmouth 製錬所では レトルト18本中の 3 本をREFRAX で建設した ことが Morgan') によつて発表された。REF $\operatorname{RAX} 1,300^{\circ} \mathrm{C}$ における破壊強度は標準 CARBOFRAXょり数倍大であり，したがつて 1,35 $0{ }^{\circ} \mathrm{C}$ で作業して生産量を 10\% 増大させるこさ が出来た。

第14表 適性比茭総括表

\begin{tabular}{|c|c|c|c|c|c|c|}
\hline & 鉱 & \multicolumn{2}{|r|}{ 種 } & 製 & 蒸 & 溜 \\
\hline 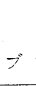 & 索 & \multicolumn{2}{|c|}{ ンヒ州 } & 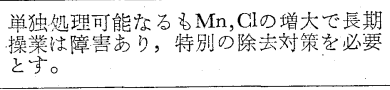 & $\begin{array}{l}\text { マーマタイト質鉄分のためレトルト侵蝕 } \\
\text { 激しく単独処理は不可。配合処理む15\% } \\
\text { 以下に止めたし。 }\end{array}$ & 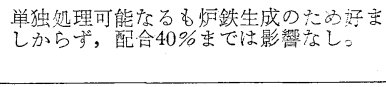 \\
\hline \multicolumn{2}{|c|}{$\begin{array}{l}\text { 豪 } \\
\text { タトナ }\end{array}$} & \multicolumn{2}{|r|}{$\begin{array}{l}\text { 州 } \\
\text { ザー 鉱 }\end{array}$} & 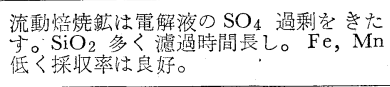 & 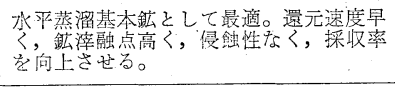 & 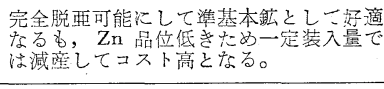 \\
\hline 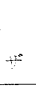 & 印 & - & 度 & 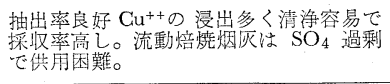 & $\begin{array}{l}\text { 還元速度逑く採取率は若干低い。レトル } \\
\text { 卜侵蝕は少ない。配合す } \\
\text { れ惊有利である。 }\end{array}$ & 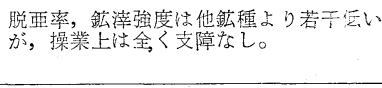 \\
\hline \multicolumn{2}{|c|}{$\begin{array}{c}\text { ビ } \\
\text { ボード }\end{array}$} & \multicolumn{2}{|c|}{$\begin{array}{lll}\text { ル } & \\
\text { ウ } & \text { ソ 鉱 }\end{array}$} & $\begin{array}{l}\text { 抽出率良好。採收率最も高し。ただ } \\
\text { Ni,Co が多く完全清浄か゚㕅介で特別の } \\
\text { 対策を必要とすす。 }\end{array}$ & 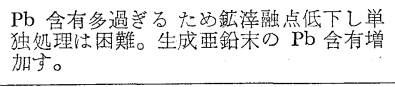 & 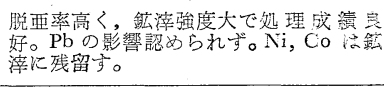 \\
\hline ヘ0 & 南 & \multicolumn{2}{|r|}{ 米 } & $\begin{array}{l}\text { 採収率高く電解良放。ただ } \mathrm{Sb}, \mathrm{F} \text { の含 } \\
\text { 有に対し清浄に特別の注意を要す。 }\end{array}$ & 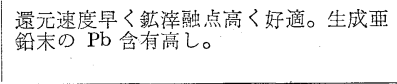 & 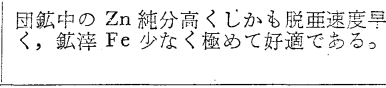 \\
\hline 力 & $\begin{array}{l}1 \\
\text { ラ }\end{array}$ & & ン 鉣 & 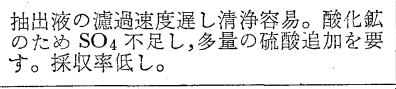 & 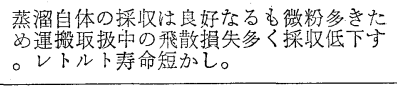 & $\begin{array}{l}\text { 配合処理は可。 } \\
\text { 単独䞘理は団啥強度低下す。 }\end{array}$ \\
\hline 神 & & 阙 & 躳 & $\begin{array}{l}\mathrm{Fe} \text { ぞの他不純物少なく単独処理の採收 } \\
\text { 率高し。電鍊処理の基本釷として好道で } \\
\text { ある。 }\end{array}$ & $\begin{array}{l}\text { 単独処理は還元速度遅く採收率若干低下 } \\
\text { す。配合処理が望䒬しい。 }\end{array}$ & $\begin{array}{l}\text { 単独または配合処理基本鉱として最適。 } \\
\text { 単独鉣の完全脱亜も可能。鈗㳯の } \mathrm{Fe} \text { 少な } \\
\text { し。 }\end{array}$ \\
\hline 中 & & 竜 & 鉱 & $\begin{array}{l}\text { 残渣生成率高く，抽出率低し。Mn 多き } \\
\text { ため単独処理は困難である。 }\end{array}$ & $\begin{array}{l}\mathrm{Fe}, \mathrm{Mn} \text { の点で基本鉱となし難し。神岡 } \\
\text { 鉣へ20\%程度の配合䞨理が最適。 }\end{array}$ & 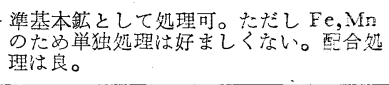 \\
\hline
\end{tabular}


三池においてはレトルト損耗に関する多くの点が解明せ られ，もつとも䀣念した炭化珪素の酸化分解がほとんど 見られず，損傷の大半が化学的侵蝕と摩耗によるもの で，側壁レンガの厚さがとくに上段において次第に薄く なつて行くことが明らかとなつた。上記 REFRAXレン ガは耐摩耗力が非常に強いので，このレンガの採用によ り高温操業も可能となり，さらにレトルト寿命の長期化 も期待されるが，吸水性が強いので築炉上になお研究の 余地加ある。

（2）レトルト寸法の大型化

レトルトの長さは最初 $6 \mathrm{ft}-3$ in としたが，その後研 究の結果炉体構造を変更することなしに $7 \mathrm{ft}$ に拡大可 能なことが明らかとなつたので，昭和 34 年未積替 4 炉分 については $7 \mathrm{ft}$ に拡大し 35 年1.月より操業再開した。そ の成績は亜鉛生産量 1 炉 1 日 $5.4 \mathrm{t}$ で従来の $15 \%$ 増とな 、り，然料原単位は従来の 0.65 より 0.55 に低下した。最 近欧米ではレトルト高さ $35 \mathrm{ft}$ のものが建設されたので, 将来の拡張時における高さの選定は一つの研究課題であ 万。

\section{（3）ガス発生炉}

立型蒸溜用発生炉のコークス原単位は創業当初に比し 漂次低下し，とくに最近発生炉余剩蒸気を利用して供用 コークスを乾燥することにより相当の効率改善が見られ
た。今日まで発生炉原料として未洗粉コークスを使用し ているが，これをさらに安価な燃料源に転換すべく目下 試験中である。

（4）高純度亜鉛生産

従来高純度垔鉛は電解法によるほか欧米においては各 種の精溜法によつて大量生産されていることは周知のと おりである。亜鉛精溜法は三池ですでに大規模の長期試 験を完了しているので，これを立型蒸溜工場に付設し立 型にて凝縮する亜鉛を液体のまま精溜塔に流し込み乾式 高純度亜鉛の生産を確立したい。

(5) 増炉問題

既述のように粉砕調合工場はすでに16炉分ないし18炉 分の能力を有するので, 今後は蒸溜炉を増設するのみで 2 倍以上の増産が達成される。しかもこの場合人員増加 は僅少でたりるのでその製鍊費は大幅に低減される。し たがつてこの増炉問題は今後の課題である。

\section{参 考 文 献}

1) W. Häning : Vergleichende Betrachtung der in Anwendung stehenden Zinkgewinnungsverfahren. ERZMETALL 1950 Jan. 22.

2) C. E. Hawke : Retort and Retort setting. U. S. Patent. 2,067, 085. 1937 Jan. 5.

3) W. Heiligenstaedt : Regeneratoren, Rekuperatoren, Winderhitzer. 193i. S. 127.

4) S. W. K. Morgan: Recent Developments in the Zinc Industry in Great Britain. Chemistry and Industry, May 1959. 614

\section{ベリリウムの}

\section{新しい検定法}

岩石中に含まれるべリリウムを簡 単に信頼できる検定法が Federal Bureau of Mines Infomation Circular 7946 で報告された。概要は 次のようである。

針金の終端に径約 $5 \mathrm{~mm}$ の小さ 輸をつくる。炎上で赤熱までその 輸を加熱する。熱い輪にフラックス （粉砕した水酸化ナトリウムペレッ ト 2 部之含水炭酸ナトリウム 3 部で 調製する)をつけ，炎上にかえして 輸内にビードをつくる。ビードがて きるまで，その操作をくりかえす。 熱い融状ビードにベリリウムを含む 粉砕岩石試料をつけ溶融する。試験 管内にビードつきの針金をいれ，5 〜 $10 \mathrm{ml}$ 水を加える。ビードを溶解 させるために試験管内の水をあたた める。針金をとりだし，溶液を冷却 してキニザリン (quinizarin) とう ルコールの希薄溶液 10 滴 $(0.25 \mathrm{~m} l)$
加える。

白色の磁製滴定板上の凹みの一つ に, この溶液の少量 $(1 \sim 2 \mathrm{~m} l)$ 注 き，短波あるいは長波の紫外光で， 暗室で検定する。ピンクないしオレ ンジ色のけい光を呈するとベリリウ 么の存在を示す。 $\mathrm{Be} 0.013 \%$ (ベリ) ルとして $0.26 \%)$ のように少量でも 検定できる。

キニザリン溶液（キナリザリン quinalizalin ではない) は $25 \mathrm{~m} l$ エ チルアルエールあるいはメチルアル コールに粉状試亚約 $1 / 4$ テースプーン 加兄て調製する。数時間放置後溶液 を口過し, 口夜は 4 倍のアルコール で希釈する。

(Bureau of Mines Develops New Field Test for Beryllium. Eng. Min. Gournal. May 1960. p. 101

（瀬川安一郎） 